\title{
SIMULASI PENSAKLARAN OTOMATIS PARALEL PORT DENGAN MENGGUNAKAN TURBO PASCAL
}

(Simulation Automatic saklar of Port Parallel using Turbo Pascal)

\author{
Rina Candra Noor Santi \\ Fakultas Teknologi Informasi UNISBANK Semarang
}

\begin{abstract}
Computer is an appliance for human which very required that good being in work at home and offices. A computer can told also a PC which able to do works of human being which do not require many time. To be result of output at that computer is maximal and good have to use peripheral of output the not badness. Like media of Printer, Modem, Fax. Peripheral of Port of output computer consist of two that is Serially Port and Parallel Ports.

But along with progress of parallel tehnologi of ports also able to be used as by link or interface with input application or equipments / other output.
\end{abstract}

\section{Keywords: Paralel port, Serial Port and Interface}

Pendahuluan

Smart office sebenarnya tidak jauh beda dengan smart home, secara garis besar smart office hanyalah sistem pemodelan maket rumah dimana didalamnya terdapat suatu rangkaian elektronika yang dapat dikontrol secara otomatis oleh komputer. Jadi hal tersebut. hanyalah perbedaan istilah saja. Rangkaian elektronika yang dipakai disini adalah 6 buah lampu dan 2 kipas angin. komputer berperan sebagai kontroller yaitu bagaimana caranya supaya rangkaian elektronika tersebut dapat berjalan secara otomatis melalui bahasa pemrograman pascal. Kaitannya dengan pemanfaatan paralel port adalah sebagai media antara computer sebagai kontroller dan rangkaian elektronika tersebut.
Sebuah PC umumnya memiliki dua buah port atau penghubung dengan peralatanperalatan input $/$ output tambahan. Dua buah port tersebut adalah serial port dan paralel port, dalam sebuah PC bisa memiliki lebih dari satu paralel port atau serial port. Pada awalnya paralel port khusus dirancang sebagai perantara atau penghubung Komputer dengan printer, namun seiring dengan kemajuan tehnologi paralel port juga bisa digunakan sebagai antarmuka atau penghubung dengan peralatan atau aplikasi input / output yang lain.

Paratel port memiliki 25 pin input $/$ output dengan konektor DB-25 female yang terdiri dari 12 gerbang output dan 5 gerbang input yang dapat kita kendalikan keluarannya dengan menggunakan instuksi-instukși dalam bahasa pemrograman. Dalam sebuah PC pengalamatan paralel port pada processor dialamatkan pada address 278h, 378h, 3BCh. Masing-masing LPT1, LPT2 dan LPT3, jadi dalam suatu processor bisa mengalamatkan sampai dengan 3 buah paralel port.

Output pada paralel port terbagi atas dua bagian yaitu terdiri dari 4 bit output control, 8 bit data output. Apabila paralel port terhubung dengan printer, setiap kali ada perintah mencetak suatu karakter dari PC, maka processor akan mengirimkan 8 bit data yang berisi karakter yang akan dicetak melalui paralel port dan mengirimkan data kontrol ke printer. 